\title{
Evaluation of Bio-agents against Different Isolates of Macrophomina phaseolina (Tassi) Goid Causing Root Rot in Castor
}

\author{
P. V. Vekariya ${ }^{1 *}$, A. G. Desai ${ }^{2}$ and G. P. Gangwar ${ }^{2}$ \\ ${ }^{1}$ Main Oilseed Research Station, Junagadh Agricultural University, \\ Junagadh-362001, Gujarat, India \\ ${ }^{2}$ Castor - Mustard Research Station, Sardarkrushinagar Dantiwada Agricultural University, \\ Sardarkrushinagar - 385506, Gujarat, India \\ *Corresponding author
}

\section{A B S T R A C T}

\begin{tabular}{l} 
K e y w o r d s \\
$\begin{array}{l}\text { Macrophomina } \\
\text { phaseolina isolates, } \\
\text { Castor root rot, } \\
\text { Efficacy of bio- } \\
\text { agents }\end{array}$ \\
\hline Article Info \\
$\begin{array}{l}\text { Accepted: } \\
\text { 26 August } 2020 \\
\text { Available Online: } \\
\text { 10 September } 2020\end{array}$ \\
\hline
\end{tabular}

The antagonistic efficacy of five different bio-agents viz., Trichoderma viride, Trichoderma harzianum, Trichoderma longibrachiatum, Pseudomonas fluorescens and Bacillus subtilis was tested against 25 isolates of Macrophomina phaseolina causing castor root rot by dual culture techniques under in vitro conditions. Variation in respect of growth inhibition of $M$. phaseolina was observed among the bio-agents as well as isolates. Among five bio-agents, significantly maximum mean growth inhibition (53.19\%) was recorded by $T$. viride followed by $T$. harzianum $(49.81 \%)$ while minimum growth inhibition (26.79 \%) was recorded by P. fluorescens followed by B. subtilis $(28.66 \%)$. Among different 25 isolates of castor root rot pathogen, significantly maximum mean growth inhibition (35.31\%) was recorded of Mp-25 followed by Mp-7 (32.83\%) which was at par with Mp-10 (32.03\%), Mp-11 (31.98 \%) and Mp-12 (31.98\%). Maximum growth inhibition of most of the isolates of $M$. phaseolina was observed by $T$. viride except Mp-4, 8, 16, 21 and 24 in which maximum growth inhibited by T. harzianum. Interaction effect of different bio-agents and isolates also showed significant variation in respect of per cent growth inhibition.

\section{Introduction}

The fungus Macrophomina phaseolina (Tassi) Goid. a soil inhabiting an important root pathogen in many crops. The disease appears at different growth stage of castor crop and hence, it is named as spike blight, stem blight, twig blight, collar rot and root rot (Moses and Reddy, 1987). Biological control is a potential non-chemical means for plant disease control by reducing the harmful effects of a pathogen through the use of other living entities. Since the M. phaseolina is a soil borne fungus and possess greater problem in managing the disease. Soil borne diseases are difficult to control. Seed treatment with fungicides does not protect the crop for long periods. Soil drenching with fungicides are not economical and they may establish imbalances in the microbial community 
unfavorable for activities of beneficial organisms (Jeyarajan et al., 1991). It is now widely recognized that biological control of plant pathogens using antagonistic fungi and bacteria is a distinct possibility for the future and can be successfully utilized especially within the framework of integrated disease management system (Muthamilan and Jeyarajan, 1996). Use of antagonistic organisms against Macrophomina root rot has been well documented in several crops (Mukhopadhyay, 1987; Raguchander et al., 1995).

\section{Materials and Methods}

\section{Collection and purification of fungal isolates}

The castor plants with typical root rot symptoms were collected from different locations of castor growing areas of Gujarat state (Table 1) and then they were subjected to tissue isolation separately on potato dextrose agar (PDA) medium in Petri plates. Purified culture disc $(5 \mathrm{~mm})$ of each of the isolates grown on PDA was transferred to PDA slant separately and incubated for four days at $30 \pm 2^{\circ} \mathrm{C}$ until the surface of PDA slant was covered with a dense sclerotial layer of the fungal culture. The culture tubes were labeled and stored at $4 \pm 1{ }^{\circ} \mathrm{C}$ temperature in refrigerator for further investigation.

\section{Collection of bio-agents}

Two fungal bio-agents viz., Trichoderma harzianum, T. viride and two bacterial bioagents viz., Pseudomonas fluorescens and Bacillus subtilis were obtained from C. P. College of Agriculture, Sardarkrushinagar Dantiwada Agricultural University, Sadarkrushinagar (Guj.), while one fungal bio-agent of $T$. longibrachiatum was obtained from Navsari Agricultural University, Navsari (Guj.).

\section{Bio assay study}

The five known bio-agents were evaluated for their effectiveness against 25 isolates of castor root rot pathogen (M. phaseolina) by dual culture technique. The test bio-agents and pathogen isolates were grown separately on solidified PDA in the sterilized Petri plates aseptically. Mycelial disc $(5 \mathrm{~mm})$ from four days old actively growing culture of bioagents and test pathogen isolates were separately cut aseptically from the periphery of the colony with the help of sterilized cork borer and placed on solidified PDA in the sterilized Petri plates aseptically approximately $60 \mathrm{~mm}$ away from each other. Test pathogen and bio-agents were subjected for growth and comparison. All inoculated Petri plates were incubated at $30 \pm 2^{\circ} \mathrm{C}$ temperature in BOD incubator. Observations on radial growth in each of the Petri plates were measured periodically and final observations were recorded when control plate was fully covered with the growth of test pathogen. The Per cent growth inhibition (PGI) was calculated by the following equation as adopted by Bliss (1934).

$$
\text { PGI }=\frac{\text { C-T }}{C} \times 100
$$

Where,

$$
\begin{aligned}
\text { PGI } & \text { Per cent growth inhibition } \\
\mathrm{C} & =\text { Colony diameter }(\mathrm{mm}) \text { in control } \\
\mathrm{T} & =\text { Colony diameter }(\mathrm{mm}) \text { in } \\
& \text { treatment }
\end{aligned}
$$

\section{Results and Discussion}

Variation in respect of growth inhibition of M. phaseolina was observed among the bioagents as well as isolates.

Among the different five antagonists, significantly maximum mean growth inhibition $(53.19 \%$ ) was recorded by $T$. viride followed by $T$. harzianum $(49.81 \%$ ) and $T$. 
longibrachiatum (41.25\%). Minimum mean growth inhibition $(26.79 \%)$ was recorded by P. fluorescens followed by B. subtilis (28.66 $\%)$.

Among the different 25 isolates, significantly maximum mean growth inhibition (35.31\%) was recorded of $\mathrm{Mp}-25$ followed by $\mathrm{Mp}-7$ $(32.83 \%)$ which was at par with $\mathrm{Mp}-10$ (32.03\%), Mp-11 (31.98\%) and Mp-12 (31.98\%). Significantly, minimum mean growth inhibition $(23.15 \%)$ was recorded in Mp-23 and was at par with Mp-8 (22.69\%).
Maximum growth inhibition of most of the isolates of M. phaseolina was observed by $T$. viride except Mp-4, 8, 16, 21 and 24 in which maximum growth inhibited by $T$. harzianum. Significantly $T$. harzianum inhibited maximum growth $(58.61 \%)$ of $\mathrm{Mp}-21$ and was statistically at par with $T$. harzianum inhibited Mp-12, T. viride inhibited Mp-2, 3, $5,7,10,13,15,17,21,22,25$ and $T$. longibrachiatum inhibited Mp-25 (55.31$58.44 \%$ inhibition). Interaction effect of different bio-agents and isolates also showed significant variation in respect of per cent growth inhibition (Table 2).

Table.1 List of isolates of M. phaseolina obtained from different locations of castor growing areas of Gujarat

\begin{tabular}{|c|l|l|l|l|}
\hline Sr. & \multirow{2}{*}{ Isolates } & \multicolumn{3}{|c|}{ Tocation } \\
\hline $\mathbf{1}$ & & \multicolumn{1}{|c|}{ Village } & \multicolumn{1}{|c|}{ District } \\
\hline $\mathbf{2}$ & Mp-1 & Sardarkrushinagar & Dantiwada & Banaskantha \\
\hline $\mathbf{3}$ & Mp-2 & Silasana & Dhanera & Banaskantha \\
\hline $\mathbf{4}$ & Mp-3 & Gathaman & Palanpur & Banaskantha \\
\hline $\mathbf{5}$ & Mp-5 & Pepalu & Lakhani & Banaskantha \\
\hline $\mathbf{6}$ & Mp-6 & Jaska & Dantiwada & Banaskantha \\
\hline $\mathbf{7}$ & Mp-7 & Vadali & Vadnagar & Mahesana \\
\hline $\mathbf{8}$ & Mp-8 & Thalvada & Vadali & Sabarkantha \\
\hline $\mathbf{9}$ & Mp-9 & Karnasar & Tharad & Mahesana \\
\hline $\mathbf{1 0}$ & Mp-10 & Gangundra & Dantiwada & Banaskantha \\
\hline $\mathbf{1 1}$ & Mp-11 & Laxmipura & Unjha & Banaskantha \\
\hline $\mathbf{1 2}$ & Mp-12 & Santalpur & Vanthali & Jahesana \\
\hline $\mathbf{1 3}$ & Mp-13 & Bagadu & Junagadh & Junagadh \\
\hline $\mathbf{1 4}$ & Mp-14 & Araniyala & Mendarda & Junagadh \\
\hline $\mathbf{1 5}$ & Mp-15 & Dervan & Keshod & Junagadh \\
\hline $\mathbf{1 6}$ & Mp-16 & Lushala & Vanthali & Junagadh \\
\hline $\mathbf{1 7}$ & Mp-17 & Barawala & Mendarda & Junagadh \\
\hline $\mathbf{1 8}$ & Mp-18 & Mendarda & Mendarda & Junagadh \\
\hline $\mathbf{1 9}$ & Mp-19 & Khumbhadi & Vanthali & Junagadh \\
\hline $\mathbf{2 0}$ & Mp-20 & Khorasha & Vanthali & Junagadh \\
\hline $\mathbf{2 1}$ & Mp-21 & Sogadi & Jamjodhpur & Jamnagar \\
\hline $\mathbf{2 2}$ & Mp-22 & Khadpipali & Mendarda & Junagadh \\
\hline $\mathbf{2 3}$ & Mp-23 & Dhutarpar & Jamjodhpur & Jamnagar \\
\hline $\mathbf{2 4}$ & Mp-24 & Jamnagar & Jamnagar & Jamnagar \\
\hline $\mathbf{2 5}$ & Mp-25 & Supedi & Dhoraji & Rajkot \\
\hline & & & & \\
\hline
\end{tabular}


Table.2 Growth inhibition of twenty-five isolates of $M$. phaseolina by different bio-agents in vitro

\begin{tabular}{|c|c|c|c|c|c|c|c|}
\hline \multirow{3}{*}{$\begin{array}{c}\text { Sr.N } \\
\text { o. }\end{array}$} & \multirow[t]{3}{*}{ Isolates } & \multicolumn{5}{|c|}{ Growth inhibition (\%) } & \multirow[t]{3}{*}{ Mean } \\
\hline & & \multicolumn{5}{|c|}{ Bio-agents } & \\
\hline & & $T h$ & $T v$ & $T l$ & $P f$ & $B s$ & \\
\hline 1 & Mp-1 & $44.98(49.97)$ & $47.56(54.46)$ & $42.40(45.48)$ & $30.52(25.79)$ & $33.75(30.87)$ & $32.20(28.40)$ \\
\hline 2 & $\mathrm{Mp}-2$ & $44.74(49.55)$ & $48.64(56.34)$ & $39.51(40.48)$ & $32.67(29.14)$ & $33.39(30.29)$ & $33.16(29.92)$ \\
\hline 3 & $\mathrm{Mp}-3$ & $44.74(49.74)$ & $48.74(56.51)$ & $44.98(47.57)$ & $33.02(29.70)$ & $32.67(29.14)$ & $34.01(31.29)$ \\
\hline 4 & $\mathrm{Mp}-4$ & $47.62(54.57)$ & $46.21(52.11)$ & $40.21(41.68)$ & $32.07(28.19)$ & $28.86(23.30)$ & $32.50(28.87)$ \\
\hline 5 & $\mathrm{Mp}-5$ & $45.40(50.70)$ & $49.45(57.74)$ & $37.93(37.79)$ & $31.85(27.85)$ & $37.24(36.62)$ & $32.50(28.87)$ \\
\hline 6 & Mp-6 & $40.94(42.94)$ & $44.10(48.43)$ & $43.31(47.05)$ & $21.45(13.37)$ & $32.26(28.49)$ & 30.34 \\
\hline 7 & $\mathrm{Mp}-7$ & $46.49(52.60)$ & $49.86(58.44)$ & $39.76(40.91)$ & $38.03(37.95)$ & $35.59(33.87)$ & 34.96 \\
\hline 8 & $\mathrm{Mp}-8$ & $41.51(43.92)$ & $40.31(41.85)$ & $32.83(29.39)$ & $23.23(15.56)$ & $32.82(29.3)$ & $28.45(22.69)$ \\
\hline 9 & Mp-9 & $44.25(48.69)$ & $47.15(53.75)$ & $41.36(43.66)$ & $36.02(34.58)$ & $37.0636 .32)$ & 34.31 \\
\hline 10 & Mp-10 & $45.40(50.70)$ & $48.73(56.49)$ & $38.02(37.94)$ & $35.96(34.48)$ & $38.9539 .52)$ & 34.47 \\
\hline 11 & Mp-11 & & $47.71(54.72)$ & $46.41(52.46)$ & & & \\
\hline 12 & Mp-12 & $48.05(55.31)$ & $46.65(52.88)$ & $40.32(41.87)$ & $34.88(32.70)$ & $36.73(35.77)$ & 34.44 \\
\hline 13 & Mp-13 & $44.90(49.83)$ & $48.83(56.66)$ & $38.65(39.01)$ & $32.43(28.76)$ & $33.50(30.46)$ & $33.05(29.74)$ \\
\hline 14 & Mp-14 & & $47.64(54.60)$ & $46.28(52.23)$ & & $26.13(19.40)$ & $31.67(27.57)$ \\
\hline 15 & Mp-15 & $43.98(48.22)$ & $47.98(55.19)$ & $36.53(35.43)$ & $34.42(31.95)$ & $34.06(31.38)$ & 32.83 \\
\hline 16 & Mp-16 & $46.74(53.04)$ & $45.57(50.99)$ & $37.29(36.7)$ & $21.64(13.60)$ & 24.34(16.99) & $29.26(23.89)$ \\
\hline 17 & Mp-17 & $45.70(51.22)$ & $48.92(56.82)$ & $39.25(40.03)$ & & $35.93(34.43)$ & $33.65(30.70)$ \\
\hline 18 & Mp-18 & $42.89(46.32)$ & $45.57(50.99)$ & $36.42(35.25)$ & $32.11(28.25)$ & $27.46(21.26)$ & $30.74(26.13)$ \\
\hline 19 & Mp-19 & $45.87(51.52)$ & $46.89(53.30)$ & $33.36(30.24)$ & $29.89(24.83)$ & $28.65(22.99)$ & $30.78(26.19)$ \\
\hline 20 & Mp-20 & $42.56(45.75)$ & $44.36(48.88)$ & $45.07(50.12)$ & $21.30(13.20)$ & $28.45(22.69)$ & $30.29(25.44)$ \\
\hline 21 & Mp-21 & $49.96(58.61)$ & $48.64(56.34)$ & $41.48(43.87)$ & $34.42(31.95)$ & $28.61(22.93)$ & $33.85(31.03)$ \\
\hline 22 & Mp-22 & $46.57(52.74)$ & $48.17(55.52)$ & $39.57(40.58)$ & $31.08(26.65)$ & $33.19(29.97)$ & $33.09(29.81)$ \\
\hline 23 & Mp-23 & $40.11(41.51)$ & $41.54(43.98)$ & $33.10(29.82)$ & $28.70(23.06)$ & $29.12(23.68)$ & $28.76(23.15)$ \\
\hline 24 & Mp-24 & $44.01(48.27)$ & $42.60(45.82)$ & $36.86(35.98)$ & $33.87(31.06)$ & $28.70(23.06)$ & $31.01(26.54)$ \\
\hline 25 & Mp-25 & $46.85(53.23)$ & $48.90(56.79)$ & $48.21(55.59)$ & $35.46(33.66)$ & $39.36(40.22)$ & $36.46(35.31)$ \\
\hline \multirow{2}{*}{\multicolumn{2}{|c|}{ Mean }} & $44.89(49.81)$ & $46.83(53.19)$ & $39.96(41.25)$ & $31.17(26.79)$ & $32.37(28.66)$ & \\
\hline & & \multicolumn{2}{|c|}{ Bio-agents } & \multicolumn{2}{|c|}{ Isolates } & \multicolumn{2}{|c|}{ Bio-agents $\times$ Isolates } \\
\hline & S. Em. \pm & \multicolumn{2}{|c|}{0.15} & \multicolumn{2}{|c|}{0.30} & \multicolumn{2}{|c|}{0.74} \\
\hline \multicolumn{2}{|c|}{ C.D. at $5 \%$} & \multicolumn{2}{|c|}{0.42} & \multicolumn{2}{|c|}{0.85} & \multicolumn{2}{|c|}{2.07} \\
\hline
\end{tabular}

Figures in parentheses are re-transformed values of arcsine transformation;

$T h=$ Trichoderma harzianum; $T v=T$. viride; $T l=T$. longibrachiatum;

$P f=$ Pseudomonas fluorescens; $B s=$ Bacillus subtilis

The fungal bio-agents $T$. viride and $T$. harzianum exhibited strong inhibition of the growth of $M$. phaseolina caused root rot in different crops (Suriachandraselvan et al., 2004; Kartikeyan et al., 2006; Chaudhary et al., 2010; Kumar et al., 2013; Karthikeyan et al., 2015). The bacterial bio-agents $P$. fluorescens and $B$. subtilis were also found effective against $M$. phaseolina caused root rot in different crops (Ahmad and Srivastva, 2000; Lokesha and Benagi, 2007; Afouda et al., 2012; Ashwini et al., 2014; Malleshwari, 
2014; Savaliya et al., 2016). The results of present study are in agreement with the earlier research workers.

\section{References}

Afouda, L.C.A., Schulz, D., Wolf, G. and Wydra, K. 2012. Biological control of Macrophomina phaseolina on cowpea (Vigna unguiculata) under dry conditions by bacterial antagonists. Inter. J. of Bio. and Chem. Sci. 6(6): 225-228.

Ahmad, S. and Srivastava, M. 2000. Biological control of dry root rot of chickpea with plant products and antagonistic micro-organism. Annu. Agri. Res. 21(3): 450-451.

Ashwini, C., Giri, G.K. and Halgekar, N.Y. 2014. Efficacy of bio-agents against seed borne fungi of black gram. Inter. J. of Apply. Bio. and Pharma. Tech. 5(3): 56-57.

Bliss, C.A. 1934. The method of probits analysis. Sci. 79: 38-39.

Chaudhary, S., Pareek, S. and Saxena, J. 2010. Efficacy of biocontrol agents singly and in combinations against dry root rot (Macrophomina phaseolina) of mungbean. $J$. of Myco. and Pl. Path. 40 (1): 141-144.

Jeyarajan, R., Ramakrishnan, G. and Sangeetha, P., 1991. Efficacy of Trichoderma as biocontrol agent for root rot disease of grain legumes. Petria, 1:143.

Karthikeyan, V., Brindha, S., Annadurai, B. and Gangwar, S.K. 2015. Biological control of Macrophomina phaseolina (Tassi) Goid. root rot in Vigna mungo (black gram) with Trichoderma spp. Inter. J. of Adv. in Bio. Res. 5(2): 118-127.

Karthikeyan, V., Sankaralingam, A. and Nakkeeran, S. 2006. Management of groundnut root rot with bio-control agents and organic amendments. Arch. of Phytopath. and
Pl. Prot. 39(3): 215-223.

Kumar, M., Gaur, V.K. and Kant, K. 2013. Evaluation of antagonists to Macrophomina phaseolina causing dry root rot in moth bean. Annu. Pl. Prot. Sci. 21(1): 163-166.

Lokesha, N.M. and Benagi, V.I. 2007. Biological management of pigeonpea dry root rot caused by Macrophomina phaseolina. Karnataka J. of Agri. Sci. 20(1): 54-56.

Malleswari, D. 2014. In vitro antagonistic activity of diverse bacterial isolates against Macrophomina phaseolina (Tassi) Goid. Inter. J. of Currunt Microbio. and Applied Sci. 3(5): 755-763.

Moses, G.J. and Reddy, R.R. 1987. Disease syndrome caused by Macrophomina phaseolina in castor. J. of Oilseeds Res. 4(2): 295-296.

Mukhopadhyay, A. N. 1987. Biological control of soil borne plant pathogens by Trichoderma spp. Ind. J. Myco. Pl. Path. 17: 1-9.

Muthamilan, M. and Jeyarajan, R. 1996. Integrated management of Sclerotium root rot of groundnut involving T. harzianum, Rhizobium and carbendazim. Ind. J. of Myco. and Pl. Patho. 26: 204-209.

Raguchander, T., Rajappan, K. and Prabhakar, K. 1995. Evaluation of talc based product of $T$. viride for the control of urd bean root rot. J. of Bio. Cont. 9: 63-64.

Savaliya, V.A., Bhaliya, C.M., Akbari, L.F., Amipara, J.D and Marviya, P.B. 2016. Biological control of Macrophomina phaseolina causing sesame (Sesamum indicum L.) root rot. The Bio. 11(2): 769-772.

Suriachandraselvan, M., Salalrajan, F., Aiyanathan, K.E.A. and Seetharaman, K. 2004. Inhibition of sunflower charcoal rot pathogen Macrophomina phaseolina by fungal antagonists. J. Myco. Pl. Path. 34(2): 364-365.

\section{How to cite this article:}

Vekariya, P. V., A. G. Desai and Gangwar, G. P. 2020. Evaluation of Bio-agents against Different Isolates of Macrophomina phaseolina (Tassi) Goid Causing Root Rot in Castor. Int.J.Curr.Microbiol.App.Sci. 9(09): 3491-3495. doi: https://doi.org/10.20546/ijcmas.2020.909.433 